UDC 539.3, 624.02

\title{
GENERAL CLASSIFICATION OF SEISMIC PROTECTION SYSTEMS OF BUILDINGS AND STRUCTURES
}

\author{
V.A. Bazhenov, \\ Doctor of Technical Science \\ Yu.D. Heraimovych, \\ Candidate of Science (Engineering) \\ Kyiv National University of Construction and Architecture \\ 31, Povitroflotsky ave., Kyiv, Ukraine, 03037
}

DOI: $10.32347 / 2410-2547.2020 .105 .3-12$

\begin{abstract}
This work complements the general classification of seismic protection systems of buildings and structures. The principles of ensuring a seismic resistance of each of the considered seismic protection systems are briefly characterized.

Keywords:seismic action, seismic protection systems of buildings and structures, classification of seismic protection systems.
\end{abstract}

\section{Introduction}

The issues of ensuring the seismic resistance of buildings and structures hold a leading position despite significant achievements in this area. This is confirmed by the significant loss of human life and destructioncaused by strong earthquakesin Indonesia (December 26, 2004; March 28, 2005;August2, 2019), China (May 12, 2008), Haiti (January 12, 2010), Chile (February 27, 2010), Mexico (April 4, 2010), Japan (March 11, 2011; November 22, 2016), Italy (August 24, 2016; October 30, 2016), Iran (November 8, 2019).

In contrast to commonly applied measures, mainly related to increasing the bearing capacity of structures, any seismic protection system associated with a significant decrease in the level of inertial forces is called active seismic protection measures [1] (1989). And it still raises some misconceptions [2] [4]. Although in 1993 Professor A.M. Uzdin proposed a seismic protection classification scheme [5]. Then he supplemented this classification in 2012 [6]. But it is also incomplete. Since then, not only a lot of time has passed, but new methods of external reduction of seismic effects and protective devices (screen) have appeared, including insensitive structures, trenches, spatial foundation platforms [7], [8].

According to the principle of operation (properties of ensuring seismic resistance), all seismic protection systems can be conditionally divided into three groups (see fig. 1).

Let us consider each of the groups in more detail.

Traditional methods of seismic protection of buildings and structures are mainly associated with reducing the mass of structures, increasing their strength and stiffness characteristics, as well as with the choice of rational planning and design solutions (fig. 2).

(C) Bazhenov V.A., Heraimovych Yu.D. 


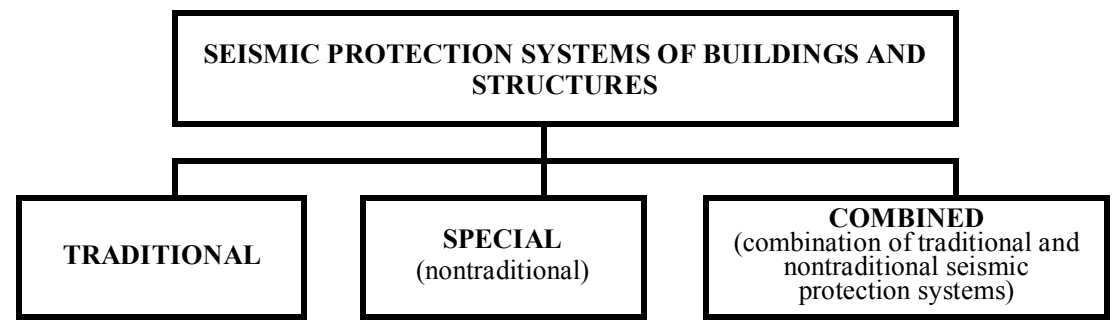

Fig. 1. General classificationof seismic protection systems

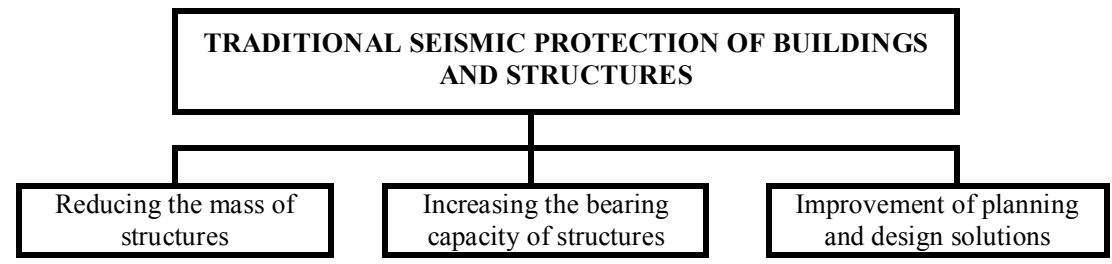

Fig. 2. Classification of traditional seismic protection

Reducing the mass of structures, with the same stiffness characteristics, leads to a decrease in inertial forces, calculated according to the linear-spectral theory laid down in the vast majority of building normsin seismic regions.

An increase in the bearing capacity of structures should guarantee the seismic resistance of structures, but the main disadvantages of this method of seismic protection are the growth of material consumption of structures, increase in cross-sections and mass of elements, which, of course, can be avoided by using materials with increased strength characteristics.

Improvements in planning and design solutions, as a rule, boil down to the fact that earthquake-resistant buildings should have simple and regular shapes both in plan and in height. If the plan has a complex form, then this can be realized by dividing the building with seismic seams into dynamically independent blocks.

To this we can add that during the construction of buildings and structures, the guaranteed quality of construction and installation work must be ensured.

The second group of seismic protection includes approaches associated with reducing the intensity of seismic loads on buildings and structures (fig. 3). Special seismic protection today is one of the most promising areas in the field of earthquake-resistant construction.

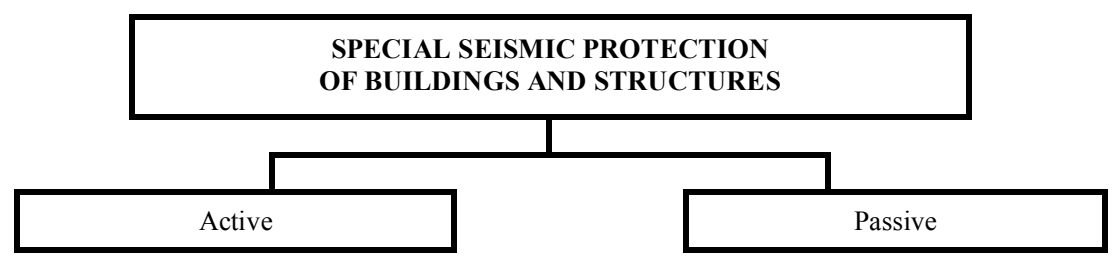

Fig. 3. Classification of specialseismic protection 
Activeseismic protection uses additional energy sources and devicesthat regulate the operation of these sources, however, its implementation requires significant costs for arrangement and operation (fig. 4). This excludes the possibility of widespread use of active seismic protection for earthquakeresistant construction. The advantage of this system is that it becomes possible to control the oscillatory process not only from seismic, but also from wind effects.

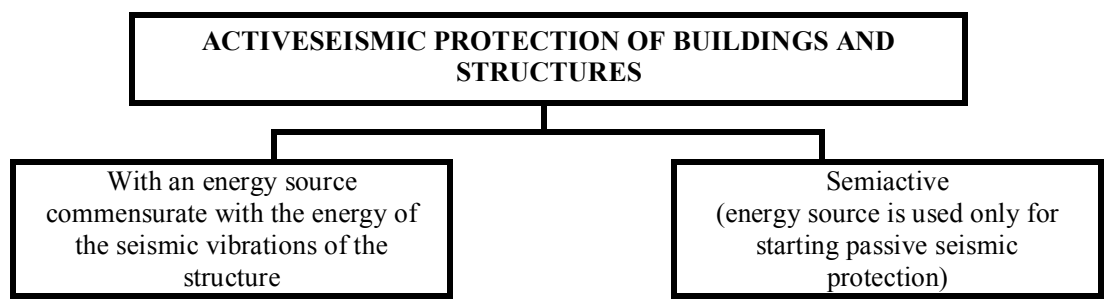

Fig. 4. Classification of active seismic protection

Passiveseismic protectionis the most numerous seismic protection groupaimed at changing the dynamic scheme of a building or structure, which is divided into seismic isolation and seismic suppression.

In seismic isolation, stationary and adaptive seismic isolation systems are distinguished. In stationary seismic isolation systems, dynamic characteristics are retained during an earthquake. And in adaptive systems, the dynamic characteristics of a building or structure change irreversibly during anearthquake, "adapting" to seismic impact. In seismic isolation systems, it's

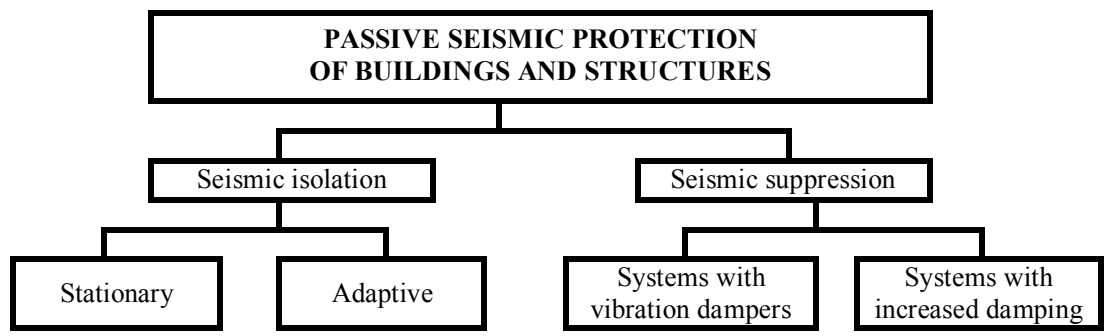

Fig. 5. Classification of passiveseismic protection

provided the reduction of mechanical energy received by a building or structurefrom the subgrade by tuning out the natural frequencies of vibrations from the prevailing frequencies of the seismic impact.

In seismic damping, systems with vibration dampers and systems with increased damping are distinguished.In thesystems with increased damping, reduction of mechanical energy is provided by the transition of mechanical energy to other types of energy. In the systems with vibration dampers, the mechanical energy of the vibrating building is converted into mechanical energy of the damper vibration. The significant disadvantages of systems with 
vibration dampers include the impossibility of using in industrial construction due to the need to adjust the damper in each individual case, as well as the relative complexity of vibration dampers.

Stationary seismic isolation of buildings and structures, in turn, is divided into internal and external. External seismic isolationaims to reduce seismic impacts through the use of design solutions that minimize the transfer of energy of seismic vibrations to the building "as a whole".

Geotechnical barriers are trenches or wells, filled with vibration-absorbing material. The advantage of geotechnical barriers is that they are invariant with respect to the frequency composition of the earthquake.

Spatial foundation platforms on a sliding layer, due to their high rigidity, have a large distribution capacity and exert little pressure on the base.

Internal seismic isolation is divided into two groups - with and without restoring force.

An example of internal seismic isolation that does not provide restoring forceisa foundationwith seismic-isolating sliding belt (seismic belt).

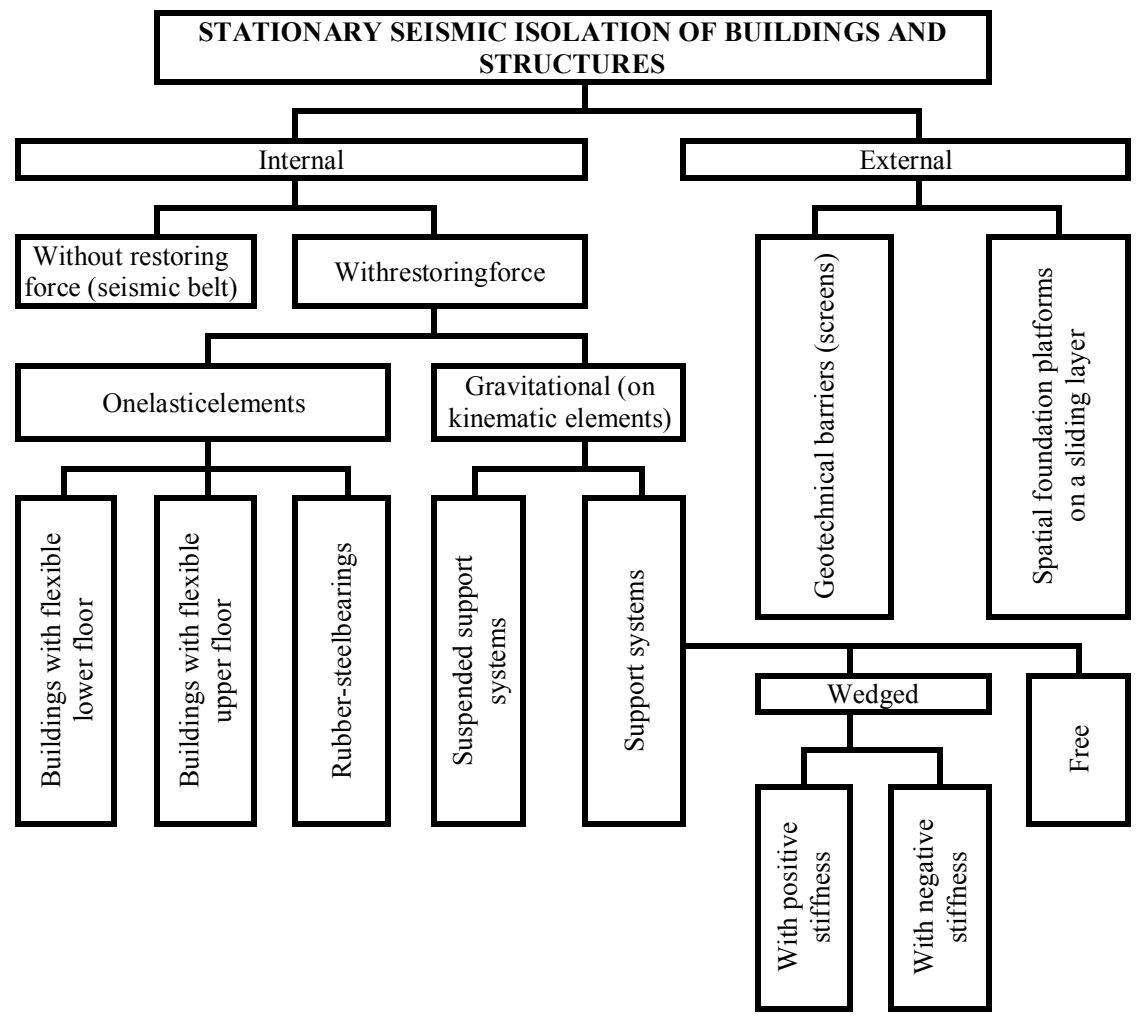

Fig. 6. Classification of stationary seismic isolation 
In turn, systems of internal seismic isolation with a restoring force are subdivided into elastic (elastic force) and gravitational (force of gravity).

Seismic-isolating foundations on elastic supports include buildings with a flexible lower floor, buildings with a flexible upper floor, as well as buildings with rubber-steelbearings.

Gravitational seismic-isolatingfoundations can be divided into suspended support systems and support systems.

In suspended support systems, the building is installed on an upper foundation slabwhich is suspended on rods from the frame structure, rigidly connected to the bottom foundation slab.

In support systems, the upper foundation slab rests on kinematic supports. According to the behavior of the supports near the rest position, the kinematic supports are subdivided into free and wedged.

Free supports react to any horizontal load on a building or structure, that is not always desirable.

Kinematic supports which include platforms or recesses in the central part of the rolling surface are called wedged. Platforms or recesses prevent the support from rolling out at low loads, and this design change led to fundamental differences in the operation of free and wedged supports.

Wedged supports can have both positive and negative stiffness.

Adaptiveseismicisolationsystemsaresystemswithswitched on and switched off connections. The features of these systems were studied in KucherenkoTs NIISK under the leadership of Ya.M. Aisenberg [9, 10].

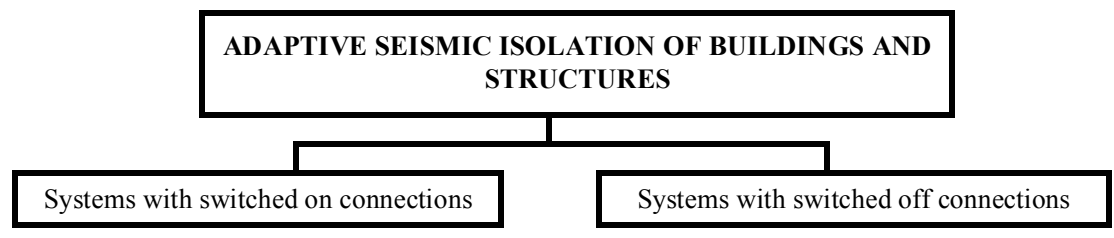

Fig. 7. Classification of adaptiveseismic isolation

Systemswithswitched on connections belong to the class of nonlinear dynamic systems with a rigid characteristic. In systemswithswitched on connections, there is no destruction of links and it is not required to restore them after an earthquake.

Systems with switched off connections belong to the class of nonstationary dynamical systems. Changes in the dynamic characteristics of such systems occur due to the destruction of switched off connections when a certain level of amplitudes is reached. After the destruction of the switched off connections during an earthquake, their immediate restoration is necessary.

Systems with vibration dampers by the nature of interaction with the protected structure are divided into dynamic and shock. Dynamic vibration dampers are divided into three groups depending on the design of the elastic connection: spring, pendularandcombineddampers [1]. The shock vibration damper is based on a massive body colliding with a special element of the protected 
structure. Floating dampers during one period of vibration of the protected structure make two successive impacts on each limiter. Spring and pendulum shock dampers differ in type of suspension and one impact per one period of vibration of the protected structure.

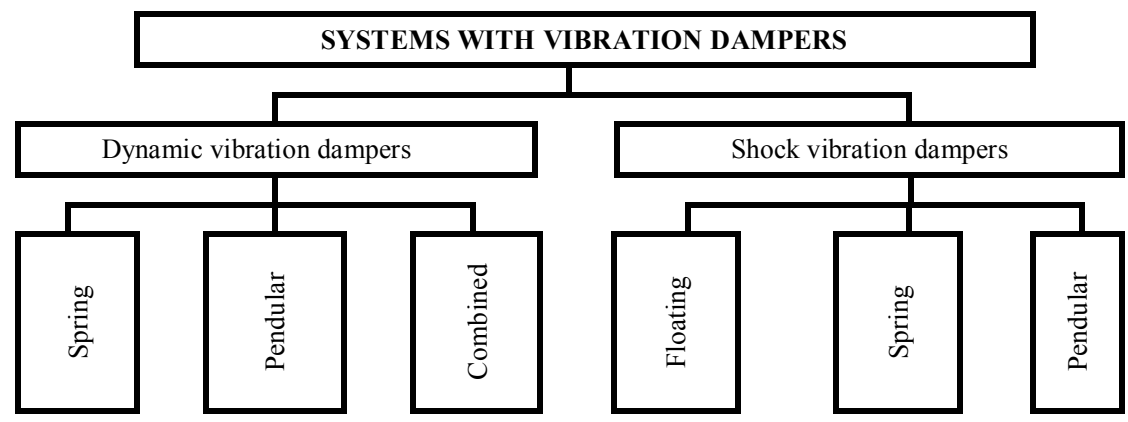

Fig. 8. Seismic suppressionsystems with vibration dampers

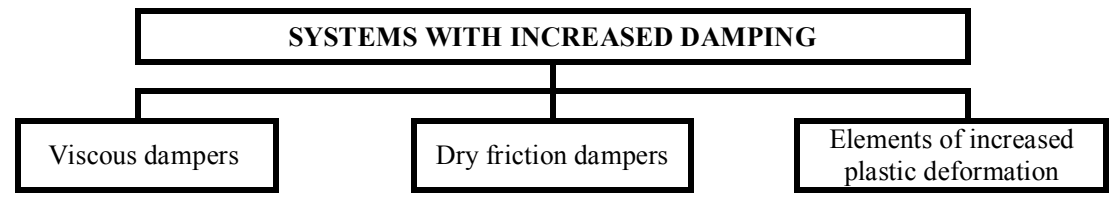

Fig. 9. Seismic suppressionsystems with increased damping

Damping devices used in the practice of earthquake-resistant construction can be conditionally divided into three groups: viscous dampers, dry friction dampers,andelements of increased plastic deformation.

Energy dissipation in viscous dampers occurs due to viscous resistance forcesthat prevent fluid flowing from one part of the damper to another.Mainly two types of viscous dampers are used: liquid and leaden.

Dry friction dampers use rubbing pairs made of different materials: metal to metal, concrete to concrete, polymer pads of various types to metal or to each other. For dry friction dampers to be effective, either a high dry friction coefficient or significant compression of rubbing pairs must be ensured.

Elements of increased plastic deformation are able to absorb the energy of seismic impactsdue to the development of inelastic deformations in the material of the energy absorber.

The massive use of seismic protection systems by design engineers is constrained by the lack of practical calculation methods. This is due to the fact that most seismic protection systems are characterized by a nonlinear deformation diagram, which does not allow the use of the standard linearspectral methodology for the calculation.

In the new edition of building codes of Ukraine [11],the section 12 "Design of building seismic isolation systems" appeared,in which passive systems for seismic isolation of buildings are considered and the main provisions for the dynamic analysis of buildings with a seismic isolation system are given. Due 
to the norms, the structures of rubber-steel seismic blocks were used for vibration and seismic protection of residential buildingsin Kyiv (10-section 10storeybuilding onKikvidze Str. and two 27-storey buildings on Obolonsky Avenue, located on the deep and shallow undergroundlines). This made it possible to achieve a decrease in vibration levels in residential premises by 7 $12 \mathrm{~dB}(2-4$ times) [12].

\section{Conclusions}

This article clarifies the general classification of seismic protection systems of buildings and structures. The use of seismic protection systems during strong earthquakes can significantly reduce the amplitude of vibrations,provide less damage to buildings and structures. Seismic protection systems are one of the most effective ways to increase the level of seismic resistance of buildings and structures, although the share of seismic-protected buildings in construction in relation to traditional ones is still very small.

\section{REFERENCES}

1. Polyakov V.S. Sovremennyye metody seysmozashchity zdaniy (Modern methods of seismic protection of buildings) / V.S. Polyakov, L.Sh. Kilimnik, A.V. Cherkashin. - M: Stroyizdat, 1989. - 320 s.(in Russian)

2. Chigrinskaya L.S. Seysmostoykost' zdaniy i sooruzheniy (Seismic resistance of buildings and structures): ucheb. Posobiye dlya studentov spetsial'nostey 270102 "Promyshlennoye i grazhdanskoye stroitel'stvo" i 270105 "Gorodskoye stroitel'stvo i khozyaystvo" / L.S. Chigrinskaya; Angarsk. gos. tekhn. akad. - Angarsk: Izd-vo AGTA, 2009. - 107 s. (in Russian)

3. Omarov Kh.M. Optimal'nyye parametry sistem aktivnoy seysmozashchity sooruzheniy s rezinometallicheskimi oporami (Optimal parameters of active seismic protection systems for structures with rubber-steel bearings) / OmarovKh.M.; Monografiya. - Makhachkala: ALEF, 2018. - 210 s. (in Russian)

4. Rashidov T.R. Prikladnyye zadachi seysmodinamiki sooruzheniy (Applied problems of seismodynamics of structures) / T.R. Rashidov, S.V. Kuznetsov, B.M. Mardonov, I. Mirzayev; Kniga 1. Deystviye seysmicheskikh voln na podzemnyy truboprovod i fundamenty sooruzheniy, vzaimodeystvuyushchikh s gruntovoysredoy. - Tashkent.: «Navro'z», 2019. 268 s. (in Russian)

5. Uzdin A.M. Osnovy teorii seysmostoykosti i seysmostoykogo stroitel'stva zdaniy i sooruzheniy (Fundamentals of the theory of seismic resistance and earthquake-resistant construction of buildings and structures) / A.M.Uzdin, T.A.Sandovich, Al'-Naser-Mokhomad Samikh Amin. S.-Peterburg: Izd-vo VNIIG im. B.Ye. Vedeneyeva, 1993. - 176 s. (in Russian)

6. Uzdin A.M. Seysmostoykiye konstruktsii transportnykh zdaniy i sooruzheniy (Earthquake resistant structures of transport buildings and structures): ucheb. posobiye / A.M. Uzdin, S.V. Yelizarov, T.A. Belash. - M.: FGBOU Uchebno-metodicheskiy tsentr po obrazovaniyu na zheleznodorozhnom transporte, 2012. -501 s. (in Russian)

7. Litvinova E.V. Innovatsionnyye sistemy seysmozashchity zdaniy i sooruzheniy zarubezhom (Innovative systems for seismic protection of buildings and structures abroad) / E.V. Litvinova, B.A. Litvinov // Resursoekonomnimaterialy, konstruktsiyi, budivli ta sporudy: zb. nauk. pr. - Vyp. 28. - Rivne, 2014. - S.386-397. (in Russian)

8. Semenov V.S. Sovremennyye sistemy seysmozashchity zdaniy i sooruzheniy. Klassifikatsiya, osnovnyye konstruktivnyye resheniya (Modern systems of seismic protection of buildings and structures. Classification, basic design solutions) / V.S. Semenov, T.V. Veremenko // Vestnik Kyrgyzsko-Rossiyskogo Slavyanskogo universiteta (KRSU). Tom 12. № 6 - Bishkek, 2012. S. 65-70. (in Russian)

9. Ayzenberg Ya.M. Adaptivnyye sistemy seysmicheskoy zashchity sooruzheniy (Adaptive systems for seismic protection of structures) / Ya.M.Ayzenberg, A.I. Neyman, A.D. Abakarov, M.M. Deglina, T.L. Chachua. - M.: Nauka, 1978. - 246 s. (in Russian)

10. Ayzenberg Ya.M. Sooruzheniya s vyklyuchayushchimisya svyazyami dlya seysmicheskikh rayonov (Constructions with switched off connections for seismic regions)/ Ya.M.Ayzenberg. - M: Stroyizdat, 1976. -229 s. (in Russian) 
11. Derzhavni budivelni normy Ukrayiny: DBNV.1.1 - 12:2014 - Budivnytstvo u seysmichnykh rayonakh Ukrayiny. (State Building Codes of Ukraine: DBN V.1.1 - 12:2014 - Construction in seismic regions of Ukraine). - K.: Ministerstvo rehionalnoho rozvytku, budivnytstva ta zhytlovo-komunalnoho hospodarstva Ukrayiny, 2014. - 110 s. (in Ukranian)

12. Nemchinov Yu.I. Vibroseysmoizolyatsiya zdaniy s pomoshch'yu sistemy elastomernykh blokov (Vibration seismic isolation of buildings using a system of elastomer blocks) / Yu.I. Nemchinov, N.G. Mar'yenkov, L.A. Zharko, A.N. Mar'yenkov, V.I. Dyrda, N.I. Lisitsa, G.N. Agal'tsov, A.V. Novikova // Budivelni konstruktsiyi. Vyp. 83(2). - Kyiv: DP NDIBK, 2016. S. 554-566. (in Russian)

Стаття надійшла 20.11.2020

\section{Баженов В. А., Гераймович Ю. Д.}

\section{ЗАГАЛЬНА КЛАСИФІКАЦІЯ СИСТЕМ СЕЙСМОЗАХИСТУ БУДІВЕЛЬ І СПОРУД}

Питання забезпечення сейсмостійкості будівель і споруд займають провідне місце, незважаючи на значні досягнення в цій галузі. Підтвердженням цього $\epsilon$ чисельні людські жертви та значні пошкодження і руйнування, що мають місце після сильних землетрусів.

За принципом роботи (властивостями забезпечення сейсмостійкості) всі системи сейсмозахисту можна умовно розділити на три групи: традиційна, спеціальна і комбінована.

Традиційні методи сейсмозахисту будівель і споруд в основному пов'язані зі зменшенням маси конструкцій, підвищенням їх міцності і характеристик жорсткості, а також з вибором раціональних планувальних і конструктивних рішень.

До другої групи сейсмозахисту відносяться підходи, пов'язані зі зниженням інтенсивності сейсмічних навантажень на будівлі і споруди. Спеціальнийсейсмозахист на сьогоднішній день $\epsilon$ одним 3 найбільш перспективних напрямків в галузі сейсмостійкого будівництва. Найчисленніша підгрупа цьогосейсмозахисту - це пасивнийсейсмозахист, спрямований на зміну динамічної схеми роботи будівлі або споруди, який, в свою чергу, ділиться на сейсмоізоляцію і сейсмогасіння.

Комбінована система має на увазі поєднання традиційної і нетрадиційної систем сейсмозахисту.

Масове застосування систем сейсмозахисту інженерами-проектувальниками стримується відсутністю практичних методик розрахунку. Це пов'язано з тим, що більшість систем сейсмозахисту характеризуються нелінійною діаграмою деформування, що не дозволяє використовувати для розрахунку нормативну лінійно-спектральну методику.

У статті уточнена загальна класифікації систем сейсмозахисту будівель і споруд. Застосування систем сейсмозахиступри сильних землетрусах здатне значно зменшити амплітуду коливань, забезпечити меншу пошкоджуваність будівель і споруд. Системи сейсмозахисту є одним з ефективних способів підвищення рівня сейсмостійкості будівель $\mathrm{i}$ споруд, хоча частка в будівництві сейсмозащіщенних будівель по відношенню до традиційних ще дуже мала.

Ключові слова: сейсмічні впливи, системи сейсмозахисту будівель і споруд, класифікація систем сейсмозахисту.

\section{Bazhenov V. A.,Heraimovych Yu. D.}

\section{GENERAL CLASSIFICATION OF SEISMIC PROTECTION SYSTEMS OF BUILDINGS AND STRUCTURES}

The issues of ensuring the seismic resistance of buildings and structures hold a leading position despite significant achievements in this area. This is confirmed by the significant loss of human life and destruction caused by strong earthquakes.

According to the principle of operation (properties of ensuring seismic resistance), all seismic protection systems can be conditionally divided into three groups: traditional, special and combined.

Traditional methods of seismic protection of buildings and structures are mainly associated with reducing the mass of structures, increasing their strength and stiffness characteristics, as well as with the choice of rational planning and design solutions.

The second group of seismic protection includes approaches associated with reducing the intensity of seismic loads on buildings and structures. Special seismic protection today is one of 
the most promising areas in the field of earthquake-resistant construction. The largest subgroup of this seismic protection - this is a passive seismic protection aimed at changing the dynamic scheme of a buildings or structures, which, in turn, is divided into seismic isolation and seismic suppression.

The combined system implies a combination of traditional and nontraditional seismic protection systems.

The massive use of seismic protection systems by design engineers is constrained by the lack of practical calculation methods. This is due to the fact that most seismic protection systems are characterized by a nonlinear deformation diagram, which does not allow the use of the standard linear-spectral methodology for the calculation.

This article clarifies the general classification of seismic protection systems of buildings and structures. The use of seismic protection systems during strong earthquakes can significantly reduce the amplitude of vibrations, provide less damage to buildings and structures. Seismic protection systems are one of the most effective ways to increase the level of seismic resistance of buildings and structures, although the share of seismic-protected buildings in construction in relation to traditional ones is still very small.

Keywords: seismic action, seismic protection systems of buildings and structures, classification of seismic protection systems.

\section{Баженов В. А., Гераймович Ю. Д.}

\section{ОБЩАЯ КЛАССИФИКАЦИЯ СИСТЕМ СЕЙСМОЗАЩИТЫ ЗДАНИЙ И СООРУЖЕНИЙ}

В работе дополнена общая классификация систем сейсмозащиты зданий и сооружений. Коротко охарактеризованы принципы обеспечения сейсмостойкости каждой из рассмотренных систем сейсмозащиты.

Ключевые слова: сейсмические воздействия, системы сейсмозащиты зданий и сооружений, классификация систем сейсмозащиты.

\section{УДК 539.3, 624.02}

Баженов В. А., Гераймович Ю. Д. Загальна класифікація систем сейсмозахисту будівель і споруд// Опір матеріалів і теорія споруд: наук.-тех. збірн. - Київ: КНУБА, 2020. - Вип. 105. - C. 3-12.-Engl.

В роботі доповнена загальна класифікаиія систем сейсмозахисту будівель $i$ споруд. Коротко охарактеризовані приниипи забезпечення сейсмостійкості кожної з розглянутих систем сейсмозахисту.

Табл. 0. Іл. 9. Бібліогр. 12 назв.

UDC 539.3, 624.02

Bazhenov V.A., Heraimovych Yu.D. General classification of seismic protection systems of buildings and structures // Strength of Materials and Theory of Structures: Scientific-andtechnical collected articles. - K.: KNUBA, 2020. - Issue 105. - P. 3-12.

This work complements the general classification of seismic protection systems of buildings and structures. The principles of ensuring a seismic resistance of each of the considered seismic protection systems are briefly characterized.

Tabl. 0. Fig. 9. Ref. 12.

УДК 539.3, 624.02

Баженов В. А., Гераймович Ю. Д. Общая классификация систем сейсмозащиты зданий и сооружений // Опірматеріалів і теоріяспоруд: наук.-тех. збірн. - Київ: КНУБА, 2020. - Вип. 105. - C. $-3-12$.

В работе дополнена общая классификачия систем сейсмозащиты зданий $и$ сооружений. Коротко охарактеризованы принципы обеспечения сейсмостойкости каждой из рассмотренных систем сейсмозащиты.

Табл. 0. Ил. 9. Библиогр. 12 назв. 
Автор (вчена ступень, вчене звання, посада): доктор технічних наук, професор, академік Національної академії педагогічних наук України, завідувач кафедри будівельної механіки Київського національного університету будівництва $i$ архітектури, директор НДI будівельної механіки БАЖЕНОВ Віктор Андрійович

Адреса робоча: 03680 Украӥна, м. Київ, Повітрофлотський проспект 31, Київський національний університет будівництва і архітектури.

Робочий тел.: +38(044) 245-48-29.

мобільний тел.: +38(067)111-22-33

E-mail: bazhenov.va@knuba.edu.ua

ORCID ID: $\mathrm{http} / /$ orcid/org/0000-0002-5802-9848

Автор (науковий ступінь, вчене звання, посада): кандидат технічних наук, докторант Київського національного університету будівництва і архітектури ГЕРАЙМОВИЧ Юрій Дмитрович

Адреса робоча: 03037 Україна, м. Київ, Повітрофлотський проспект 31, Київський національний університет будівництва $i$ архітектури, відділ докторантури та аспірантури, ГЕРАЙМОВИЧУ Юрію Дмитровичу

Робочий тел.: +38(044) 246-16-20;

Мобільний тел.: +38(067) 238-73-19;

E-mail: yury_geraimovich@ukr.net

ORCID ID: http://orcid.org/0000-0002-5605-5276 